\title{
Strategies for Community Participation in Pre-Disaster Phase in the Gaza Strip, Palestine
}

\author{
"Adnan Enshassi', Sobhi Shakalaih² and Suhair AlKilani
}

\begin{abstract}
Published online: 25 January 2019
To cite this article: Adnan Enshassi, Sobhi Shakalaih and Suhair AlKilani (2018). Strategies for community participation in pre-disaster phase in the Gaza Strip, Palestine. Journal of Construction in Developing Countries, 23(2): 107-127. https://doi.org/10.21315/jcdc2018.23.2.7.
\end{abstract}

To link to this article: https://doi.org/10.21315/jcdc2018.23.2.7

\begin{abstract}
The objective of this paper is to identify and investigate the strategies utilised by local communities in the Gaza Strip, Palestine in pre-disaster stage. Twenty four community participation-pre-disaster strategies were compiled from the literature and refined according to the pilot study. A purposive sampling method of 86 community members in neighborhood committees was employed to collect the data. The results obtained from the exploratory factor analysis clustered the community participation strategies into three components, namely: preparing effective coordination and management plans, preparing information and knowledge system and providing early warning and communication plans. NonGovernmental Organisations (NGOs) in Gaza governorates require a common understanding of what creates effective disaster preparedness system. Risks threatening Gaza Strip cannot be prevented, but their human, socio-economic and environmental impacts can and should be minimised through appropriate measures, including early warning. The early warning system in Gaza governorates is considered weak and need to be developed. There is a need to disseminate early warning protocols of every type of risks in Gaza Strip for local communities. The findings of this research will be significant concerning the present and future of organisational planning and management by both governmental and NGOs regarding disaster management practice and community participation in pre-disaster phase.
\end{abstract}

Keywords: Disaster, Management, Community, Strategy, Factor analysis

\section{INTRODUCTION}

Disaster is defined as "a serious breach of the daily life of people in a community, causing serious losses, as human life, flora and fauna, trade and industrial activities resulting in failure of a community to meet the situation that resources could be reduced" (Baas et al., 2008: 4). According to the United Nations International Strategy for Disaster Reduction (UNISDR) (2009), disasters represent "a serious disruption of the functioning of a community or a society involving widespread human, material, economic or environmental losses and impacts, which exceeds the ability of the affected community or society to cope using its own resources" (p. 9). Disaster management is a process that comprises strategies and actvities to improve the impacts and to mitigate the risk of disasterinvolving pre-disater phase and emergency operation and rebuilding the society after the occurrence of devastating disaster (Huq, 2016). The community involvement by adopting the tools and methods of

\footnotetext{
'Department of Civil Engineering, IUG, Gaza Strip, PALESTINE ${ }^{2}$ Palestine Red Crescent Society (PRCS), Gaza Strip, PALESTINE ${ }^{3}$ University of New South Wales (UNSW), AUSTRALIA

"Corresponding author: aenshassi@gmail.com
} 
disaster risk reduction plays an important role in disaster management process (Hossain, 2012). At a fundamental level, disaster management requires balancing practical matters with community participation (Federal Emergency Management Agency [FEMA], 2017; Kapucu, 2008). Early planning and advanced development of disaster strategies can significantly reduce the impact of the disaster. Community based disaster management plans integrated with development plans can initiate locally appropriate disaster reduction strategies and development activities (Practical Action, 2011).

The Human Development Report by the United Nations Development Programme (2009) revealed that Gaza Strip has a poor experience in managing disaster and disaster management system was accused of being incapable to cope with disasters. Aldbeek (2010) found that there is an urgent need to plan for disaster risk reduction at Palestine and linkage to the international system. This plan should defines the roles and responsibilities of national organisations, management plans should be proactive, giving emphasis to preparedness and mitigation. Enshassi and Abu Zaiter (2013) explored the self-help approach in housing reconstruction and beneficiary's satisfaction in Palestine. They emphasised that communities and households must have a strong voice in determining the post-disaster reconstruction approaches and a central role in the reconstruction process. Further, Enshassi and Shakalaih (2016) investigated community based disaster risk reduction (DRR) in Gaza Strip. They recommended to analyse the existing DRR frameworks to assess effectiveness in promoting the community level of DRR activities and in empowering community involvements. Disaster management in Palestine requires efforts from many disciplines from all levels of the national authorities and the civil society organisations, each according to its scope and competence, and requires all to work together in an integrated approach. There is a lack of focus on disaster preparedness in comparison to post-disaster response management (Enshassi and Shatat, 2012). Therefore, the objective of this paper is to investigate the strategies that are utilised by local communities in the Gaza Strip, Palestine in pre-disaster stage.

\section{Disaster Management}

According to Vasilescu et al. (2008), disaster management comprises all activities, programmes, and measures, which can be taken up before during, and after a disaster with the aim to avoid a disaster, reduce its impact, or recover from its losses. Warfield (2008) stated that the main goal of disaster management is to reduce, avoid potential losses from hazards and develop rapid response and recovery effectively. In an attempt to understand the disaster management, researchers use the term of disaster management cycle, which describes the ongoing processes that is used by governments, institutions and civil society in disaster management plan, and interact with them before, during, and after the disaster. Appropriate actions in the cycle lead to effective preparedness, better warnings, reduced vulnerability, or the prevention of disasters during the following phase of the cycle. According to Holloway (2003), the typical disaster management cycles, comprises two overarching phases and these can be described as the pre-disaster and the post-disaster phases respectively. Khan and Khan (2008) divided the cycle into three phases, which can be divided into a post-disaster response phase, post-disaster recovery phase and a pre-disaster mitigation and preparedness. Vasilescu et al. (2008) identified three key stages of activities that are taken up within disaster risk 
management: (1) before a disaster (pre-disaster) activities; those which are taken to reduce human and property losses caused by a potential hazard, (2) during a disaster (disaster occurrence) that include initiatives taken to ensure that the needs and provisions of victims are met and suffering is minimised; activities taken under this stage are called emergency response activities and (3) after a disaster (postdisaster), which are the initiatives taken in response to a disaster with a purpose to achieve early recovery and rehabilitation of affected communities, immediately after a disaster strikes; these activities are called as response and recovery activities.

On the other hand, Coppola (2015) stated that a comprehensive disaster management is based upon four distinct components: mitigation, preparedness, response and recovery. Twigg (2004: 13) defined mitigation as "any action to minimise the impact of potential disaster. This ranges from physical measures such as flood defenses or reinforcing buildings to non-structural measures, such as training, land use regulations, legislations, economic mechanisms, and raising public awareness. Mitigation can take place at any time before, during, or after a disaster". UNISDR (2009: 19) defined disaster mitigation as "structural and nonstructural measures undertaken to limit the adverse impact of natural hazards, environmental degradation and technological hazards". According to FEMA (2000: 1), mitigation is defined as "sustained action taken to reduce or eliminate the longterm risk to people and property from hazards and their effects". FEMA (2000) added that disaster mitigation can be structural, such as, mitigating hazards to prevent a disaster, as well as non-structural, for example, mitigating the vulnerability of a community to reduce the impacts of a disaster.

McEntire (2005) argued that the goal of mitigation is to reduce human vulnerability to disasters through hazard assessments, emergency exercises, improved engineering, and public education. Cyganik (2003) placed mitigation at the base, proposing that it is dynamic forces behind an effective response. According to Abramovitz et al. (2001), mitigation is noticeably part of a wider in scale strategy of sustainable development which simply means making communities and nations ecologically, economically and socially sustainable. Haddow et al. (2006) pointed out that the mitigation is essential in disaster management, because it leads to the creation and implementation of codes and actions to protect property from potential disasters.

International Federation of Red Cross and Red Crescent Societies (IFRC) (2000: 6) defined the preparedness as "measures taken to prepare for and reduce the effects of disasters. That is, to predict and-where possible-prevent them, mitigate their impact on vulnerable populations, and responds to and effectively cope with their consequences". Stephenson (1994) stated that preparedness is the actions of individual, community and administrative action to minimise loss of life and damage and facilitate effective rescue, relief and rehabilitation. Disaster preparedness usually refers to measures and actions taken in advance to confirm effective response to the impact of disasters. This include the issuance of timely and effective early warnings and the temporary displacement of people and property from a vulnerable location. The measures that ensure the readiness and ability of a society include: forecasting and taking precautionary measures in advance of an imminent threat and responding to and coping with disaster effects by organising and delivering timely and effective assistance (UNISDR, 2004). Twigg (2004) clarified that the main aim of disaster preparedness, is to help people avoiding impending disaster threats and putting plans, resources and mechanisms in place to ensure that those who are affected receive adequate assistance. 
Twigg (2004) argued that responses are measures undertaken to ensure survival and prevent further snowballing of the situation, such measures include search and rescue, immediate repair and restoration of serious facilities and services, carrying out damage needs and capacity assessment, food and non-food relief assistance, evacuation center management, networking and medical assistance. The provision of emergency services and public assistance during or immediately after a disaster to save lives, reduce health impacts, ensure public safety, and meet the basic life needs of the people affected (UNISDR, 2009). Response mechanisms indicate the measures to be taken between the community and organisations, allowing that different agencies ensure that the response actions and resources are not duplicated (Kent, 1994). Disaster management recovery refers to the activities that are taken after the initial impact to advance environmental and socioeconomic situations that are damaged by disaster aimed at accomplishing return to the normal state. That is to say, the recovery phase has been placed at the top, for it is the only thing remains after the response (Kapucu, 2008).

Furthermore, it takes the major extent of time and the greatest cost (Cyganik, 2003). There are mitigating measures, such as, financial assistance to relocate families, safer homes and provision of water, sanitation and electricity and more stringent enforcement of building codes in reconstruction. These measures could lead to disaster risk reduction and encourage a culture of safety (Wisner, et al., 2003). According to Kapucu and Garayev (2011), during the last decade the traditional emergency, crisis and disaster management tools have proved to be ineffective, mainly due to the increase of the frequency and scope of natural and human made disasters. Thus, Kapucu and Garayev (2011) suggest a collaborative emergency management approach that is a collaborative decision-making which focuses on the application of networked coordination, collaboration and partnerships in crisis, disaster and emergency settings. Hossain (2012) concluded that for disaster management, to be effective, it should compine prevention, preparedness, mitigation, emergency response and recovery to cope with hazardous situation.

\section{Comunity Participation in Disaster Management}

Community participation, generally, refers to the involvement of people in any project to solve their own problems or to develop their socio-economic conditions. It concludes their participation in setting goals, and preparing, implementing and evaluating plans and programs (Hossain, 2012). Community participation is regarded as a key aspect to achieve sustainability in dealing with natural disaster risks (Huq, 2016). The most common elements of community involvement are partnership, participation, empowerment and ownership by the local people (Rajeev, 2014). Community empowerment is identified as a type of capacity development where its members decide on the goals and strategies for disaster risk management provide the resources needed, and monitor their performance (Asian Disaster Preparedness Centre [ADPC], 2004). The empowerment of communities is usually utilised to identify their own needs, which is called "community-based" approaches (Wiek et al., 2010). Newport and Jawahar (2003) and Metri (2006) reported that community participation in the pre-disaster phase should include: engaging community voluntary work, meeting and awareness programs strengthen the Non-Governmental Organisations (NGOs) and community structures, coordination 
effective management with operational planning, participating in risk assessment and information flow by early warning system. Sadiai et al. (2015) stated that lack of community involvement often leads to poor project planning, decreased community support and an unsustainable completed project.

Mathbor (2007) reported that community participation strategies in pre disaster comprise: enhance the community awareness, coordinating disaster management and development (economic and environmental levels) activities, capacity building at the social, economic and environmental levels, preparing community preparedness plans, educating people on how to mitigate the disaster impact, strengthening the capacities of related NGOs, playing an enormous role in providing psychological support, assessing the impact of disasters, utilising communication for disseminating warning signals and engaging local volunteers with the local logistics, resources and coordination plan. Palakudiyil and Todd (2003) reported that disaster management should be used in a way that respects the views of the community and encourages participation at all stages including prevention and mitigation. Venton and Hansford (2006) reported that the most effective way to reduce disaster risk is to work with local people to identify and analyse their vulnerabilities and capacities and to develop and implement an action plan. Consequently, they introduced an approach to achieve this, which they called Participatory Assessment of Disaster Risk (PADR). Venton and Hansford (2006) clarified that participatory assessment of disaster risk is carried out where local communities have identified a need to reduce disaster risk. Create a balance in the participatory approach that is reflected from the pursuit of decisiveness and negotiates about the problems and needs should be identified by the community (Wiek et al., 2010). UNISDR (2010) reported that many organisations have developed various participatory approaches concerning communities with the purpose of addressing cultural concerns in the post disaster development processes in good practices in the Asia Pacific region. Barakat (2003) indicated that the community participation after disaster is supporting housing construction handled by donor organisations and NGOs.

The last decade has witnessed a paradigm shift in viewing disaster and appaches to disaster management. While a few years ago disasters were viewed as "one-off events" and only responded by governments and relief agencies without taking into account the social and economic implications and causes of these events, the recent approachs imphasise on community participation, which considered as a key aspect in disater management (Hosseini et al., 2014). In particular, during this paradigm shift there has been great emphasising that disaster mitigation is immensely effective at the community level (Murshed, 2003: 145), mainly because the community themselves are the first responders and victims (Ritchie, 2003). Consequently, the governments of different countries have adopted comprehensive disaster management strategies and programs, emphasising on community participation.

Disaster-prone community should be empowered with proper training and necessary information (Hosseini et al., 2014) at both pre-disater and post disaster phases through effective community participation strategies (FEMA, 2017). Effective pre-disaster streatigies and planning allow a comprehensive understanding of community objectives. In addetion, it links community plans to guide post-disaster decisions. Which in turn aid in understanding the important processes and decisions that a local government can use to build a community's recovery capacity. 
The ability of a community to successfully manage the recovery process begins with its efforts in pre-disaster. In this essence, a pre-disaster recovery planning promotes a process in which the whole community fully engages in providing leadership in developing recovery priorities and activities that are realistic, well planned and clearly communicated (FEMA, 2017).

Therefore, at pre-disaster phase, an effective planning should be in place that ensures that the community is better situated and involved to address preexisting local needs, take advantage of available resources and seize opportunities to increase local resiliency, sustainability, accessibility and social equity (FEMA, 2017; Mathbor, 2007; Rajeev, 2014). At the post-disater phase, communities must be ready to understand and adapt to the new conditions and to create a desirable future based on these circumstances. Doing these things successfully requires the effective community participation strategies and planning in place. It can be concluded that without an organised community participation strategies and planning to be implemented pre- and post-disaster, recovery may occur but is likely to be uneven, slow, and inefficient (FEMA, 2017). The most important community participation strategies are illustrated in Table 1. Those 24 strategies are used to develop the data collection instrument for this sudy.

\section{METHODOLOGY: DATA COLLECTION AND ANALYSIS METHODS}

A questionnaire survey was employed in this study, which is the most widely used data-gathering technique in research and can be used to measure issues that are related to the management and development of human resources, such as behavior, attitudes, beliefs, opinions, characteristics and expectations (Anderson, 2004). A pilot study was conducted, whereas five experts from different professionals have reviewed the questionnaire and made adjustments that best fit the local conditions, such as loaded statements, double statements, ambiguous statements, inappropriate vocabulary and missing issues. Accordingly, the questionnaire was revised by taking into consideration the experts comments.

The final questionnaire consisted of two main sections: the first section was general information about the respondents and their organisations and the second section of the questionnaire comprises statements related to community participation strategies in pre-disaster management. The respondents were asked to rate the degree of the importance of the presented pre-disaster management strategies according to their experience with NGOs in the Gaza Strip. Five-point Likert scale was used: where, 1 is the "Least important" and 5 is the "Most important". Cronbach alpha coefficient (Cronbach, 1951) was utilised to test the reliability of the questionnaire. The Cronbach's alpha coefficients was found above 0.7, which means that the test is reliable (Polit and Hungler, 1999). 
Table 1. Community Participation Strategies

\begin{tabular}{|c|c|c|c|}
\hline No. & Participation Strategies & Sources & Comments \\
\hline 1 & $\begin{array}{l}\text { Provide varies educational } \\
\text { background regarding disaster } \\
\text { management }\end{array}$ & $\begin{array}{l}\text { Kangabam, C. and Kangabam } \\
\text { (2012), Nirupama and Ełkin (2012) } \\
\text { and Mathbor (2007) }\end{array}$ & Modified \\
\hline 2 & $\begin{array}{l}\text { Provide appropriate community } \\
\text { based disaster preparedness } \\
\text { plan }\end{array}$ & $\begin{array}{l}\text { Kangabam, C. and Kangabam } \\
\text { (2012), Said et al. (2011) and } \\
\text { Mathbor (2007) }\end{array}$ & Merged \\
\hline 3 & $\begin{array}{l}\text { Prepare information technology } \\
\text { system regarding disaster } \\
\text { management }\end{array}$ & $\begin{array}{l}\text { Kangabam, C. and Kangabam } \\
(2012) \text {, Metri (2006) and Newport } \\
\text { and Jawahar (2003) }\end{array}$ & Modified \\
\hline 4 & $\begin{array}{l}\text { Strengthen relationships between } \\
\text { non-government organisations } \\
\text { and community-based } \\
\text { organisations related disaster } \\
\text { management }\end{array}$ & $\begin{array}{l}\text { Kangabam, C. and Kangabam } \\
\text { (2012), Nirupama, and Etkin (2012), } \\
\text { Said et al. (2011), Metri (2006) and } \\
\text { Newport and Jawahar (2003) }\end{array}$ & Modified \\
\hline 5 & $\begin{array}{l}\text { Propose a public awareness } \\
\text { programs and preparedness } \\
\text { knowledge }\end{array}$ & $\begin{array}{l}\text { Nirupama and Etkin (2012), } \\
\text { Said et al. (201 1), Mathbor (2007), } \\
\text { Metri (2006) and Newport and } \\
\text { Jawahar (2003) }\end{array}$ & Modified \\
\hline 6 & $\begin{array}{l}\text { Meet the various sectors } \\
\text { which are relevant to disaster } \\
\text { management }\end{array}$ & Nirupama and Ełkin (2012) & Modified \\
\hline 7 & $\begin{array}{l}\text { Strengthen the role of institutions } \\
\text { to participate in disaster } \\
\text { management activities }\end{array}$ & $\begin{array}{l}\text { Kangabam, C. and Kangabam } \\
\text { (2012), Nirupama, and Etkin (2012), } \\
\text { Said et al. (2011), Metri (2006) and } \\
\text { Newport and Jawahar (2003) }\end{array}$ & Modified \\
\hline 8 & $\begin{array}{l}\text { Create a continuous dialogue } \\
\text { between the institutions and } \\
\text { stakeholders }\end{array}$ & Nirupama and Ełkin (2012) & Modified \\
\hline 9 & $\begin{array}{l}\text { Provide mitigation programs for } \\
\text { risk disaster }\end{array}$ & $\begin{array}{l}\text { Nirupama and Etkin (2012) and } \\
\text { Mathbor (2007) }\end{array}$ & Modified \\
\hline 10 & $\begin{array}{l}\text { Disseminate information of } \\
\text { disaster topics and encourage } \\
\text { public participation }\end{array}$ & Nirupama and Ełkin (2012) & Modified \\
\hline 11 & $\begin{array}{l}\text { Provide emergency response } \\
\text { plan }\end{array}$ & $\begin{array}{l}\text { Kangabam, C. and Kangabam } \\
\text { (2012), Said et al. (2011) and } \\
\text { Mathbor (2007) }\end{array}$ & Merged \\
\hline 12 & $\begin{array}{l}\text { Establish capability-building } \\
\text { activities between the } \\
\text { community disaster committees } \\
\text { and volunteers }\end{array}$ & $\begin{array}{l}\text { Said et al. (201 1), Mathbor (2007), } \\
\text { Metri (2006) and Newport and } \\
\text { Jawahar (2003) }\end{array}$ & Merged \\
\hline 13 & $\begin{array}{l}\text { Provide early warning protocols } \\
\text { and evacuation plans }\end{array}$ & $\begin{array}{l}\text { Said et al. (201 1), Mathbor (2007), } \\
\text { Metri (2006) and Newport and } \\
\text { Jawahar (2003) }\end{array}$ & Modified \\
\hline
\end{tabular}


Table 1. (continued)

\begin{tabular}{|c|c|c|c|}
\hline No. & Participation Strategies & Sources & Comments \\
\hline 14 & $\begin{array}{l}\text { Coordinate disaster } \\
\text { management and development } \\
\text { (economic and environmental } \\
\text { levels) activities }\end{array}$ & $\begin{array}{l}\text { Mathbor (2007), Metri (2006) and } \\
\text { Newport and Jawahar (2003) }\end{array}$ & Modified \\
\hline 15 & $\begin{array}{l}\text { Strengthen the capacities of } \\
\text { related NGOs }\end{array}$ & $\begin{array}{l}\text { Mathbor (2007), Metri (2006) and } \\
\text { Newport and Jawahar (2003) }\end{array}$ & Modified \\
\hline 16 & $\begin{array}{l}\text { Providing psychological support } \\
\text { for communities }\end{array}$ & Mathbor (2007) & Modified \\
\hline 17 & $\begin{array}{l}\text { Assess the impact of recent } \\
\text { disasters }\end{array}$ & $\begin{array}{l}\text { Mathbor (2007), Metri (2006) and } \\
\text { Newport and Jawahar (2003) }\end{array}$ & Modified \\
\hline 18 & $\begin{array}{l}\text { Utilise communication for } \\
\text { disseminating warning signals }\end{array}$ & $\begin{array}{l}\text { Said et al. (201 1), Mathbor (2007), } \\
\text { Metri (2006) and Newport and } \\
\text { Jawahar (2003) }\end{array}$ & Modified \\
\hline 19 & $\begin{array}{l}\text { Engaging local volunteers with } \\
\text { the local logistics }\end{array}$ & $\begin{array}{l}\text { Said et al. (201 1), Mathbor (2007), } \\
\text { Metri (2006) and Newport and } \\
\text { Jawahar (2003) }\end{array}$ & Merged \\
\hline 20 & $\begin{array}{l}\text { Preparing resources and } \\
\text { coordination plan }\end{array}$ & Mathbor (2007) & Modified \\
\hline 21 & $\begin{array}{l}\text { Engage community voluntary } \\
\text { work }\end{array}$ & Mathbor (2007) & Merged \\
\hline 22 & $\begin{array}{l}\text { Coordinate effective } \\
\text { management with operational } \\
\text { planning }\end{array}$ & $\begin{array}{l}\text { Metri (2006) and Newport and } \\
\text { Jawahar (2003) }\end{array}$ & Modified \\
\hline 23 & Participate in risk assessment & $\begin{array}{l}\text { Mathbor (2007), Metri (2006) and } \\
\text { Newport and Jawahar (2003) }\end{array}$ & Modified \\
\hline 24 & $\begin{array}{l}\text { Draft capacity building } \\
\text { programmes in a bottom-up and } \\
\text { demand-driven fashion }\end{array}$ & Mengers (2000) & Modified \\
\hline
\end{tabular}

There are 148 neighborhoods located in Gaza Strip and distributed through five governorates (as shown in Table 2), namely: 28 neighborhoods in northern governorate, 27 neighborhoods in Gaza, 31 neighborhoods in the central governorate, 41 in Khanyounis and 21 in Rafah (Ministry of Local Governments [MoLGs], 2013). The neighborhood committees' members were considered for the survey since they can present other members and lead the committees' activities.

Purposive sampling was used in this study. Parahoo (1997) describes purposive sampling as a method of sampling where the researcher deliberately chooses the respondents based on their ability to provide necessary data. The rationale for choosing this approach was that the research was seeking knowledge about the communities' opinion, which the participants would provide by virtue of their experience. The researchers have visited the 148 neighborhood committees in the five districts in the Gaza Strip. It was found that 90 committee members have been involved and participated in disaster management process. Therefore, 90 community members were targeted with personal delivery: 86 questionnaires were completed with $95.5 \%$ response rate (Table 3 ). 
Table 2. Neighborhood Committees

\begin{tabular}{lcc}
\hline District & Neighborhood Committees & Percentage (\%) \\
\hline Northern governorate & 28 & 19 \\
Gaza governorate & 27 & 18 \\
Central governorate & 31 & 21 \\
Khanyounis governorate & 41 & 28 \\
Rafah governorate & 21 & 14 \\
Total & 148 & 100 \\
\hline
\end{tabular}

Source: MoLGs (2013)

Table 3. Sample Size of Respondents

\begin{tabular}{lccc}
\hline District & $\begin{array}{c}\text { Neighborhood } \\
\text { Committees }\end{array}$ & $\begin{array}{c}\text { Sampling } \\
\text { Size }\end{array}$ & $\begin{array}{c}\text { No. of } \\
\text { Respondents }\end{array}$ \\
\hline Northern governorate & 28 & 17 & 16 \\
Gaza governorate & 27 & 17 & 16 \\
Middle governorate & 31 & 19 & 18 \\
Khanyounis governorate & 41 & 25 & 23 \\
Rafah governorate & 21 & 13 & 13 \\
Total & 148 & 90 & 86 \\
\hline
\end{tabular}

Exploratory factor analysis (EFA) was used in this study, which operates on the notion in which measurable and observable variables can be reduced to fewer latent variables that share a common variance and are unobservable, which is known as reducing dimensionality (Bartholomew et al., 2011; Yong and Pearce, 2013).

\section{RESULTS AND DISCUSSION}

\section{Demographic Survey of Respondents}

Table 4 illustrates the respondents' profile in terms of gender, age, educational level, respondents' profession, working experience in the committee, governorate which committee belongs to, city population and committee establishment. The majority of respondents were male (88.4\%), there were (39.5\%) family leaders, their age more than 50 years with a percentage of $(51.1 \%)$. Respondent's experience indicated that $38.4 \%$ had between six and 10 years' experience. $36 \%$ had experience in community work more than 10 years. The majority of respondents were operating in the Khanyounis governorate (26.7\%) and their city population between 150,000 and 300,000. Most of local committees have been established after 2000. 
Table 4. Respondents' Profile

\begin{tabular}{|c|c|c|c|}
\hline Personal Information & Categories & Frequency & Percentages \\
\hline \multirow[t]{2}{*}{ Gender } & Male & 76 & 88.4 \\
\hline & Female & 10 & 11.6 \\
\hline \multirow[t]{4}{*}{ Age } & Less than 25 years old & 0 & 0 \\
\hline & $25-35$ years old & 7 & 8.1 \\
\hline & $36-50$ years old & 35 & 40.7 \\
\hline & More than 50 years old & 44 & 51.2 \\
\hline \multirow[t]{4}{*}{ Educational level } & Secondary school & 11 & 12.8 \\
\hline & Diploma & 27 & 31.4 \\
\hline & Bachelors & 37 & 43.0 \\
\hline & Master & 4 & 4.7 \\
\hline \multirow[t]{7}{*}{ Profession } & Engineer & 12 & 14.0 \\
\hline & Teacher & 13 & 15.1 \\
\hline & Nurse & 6 & 7.0 \\
\hline & Director of organisation & 8 & 9.3 \\
\hline & Political activist & 6 & 7.0 \\
\hline & Secretary & 7 & 8.1 \\
\hline & Family leader & 34 & 39.5 \\
\hline \multirow[t]{4}{*}{ Experience (years) } & Less than three years & 10 & 11.6 \\
\hline & $3-5$ years & 12 & 14.0 \\
\hline & $6-10$ years & 33 & 38.4 \\
\hline & More than 10 years & 31 & 36.0 \\
\hline \multirow[t]{5}{*}{ Governorate } & Northern governorate & 16 & 18.6 \\
\hline & Governorate of Gaza & 16 & 18.6 \\
\hline & Central governorate & 18 & 20.9 \\
\hline & Governorate of Khanyounis & 23 & 26.7 \\
\hline & Governorate of Rafah & 13 & 15.1 \\
\hline \multirow[t]{4}{*}{ City population } & Less than 50,000 & 19 & 22.1 \\
\hline & $50,000-150,000$ & 14 & 16.3 \\
\hline & $150,000-300,000$ & 31 & 36.0 \\
\hline & More than 300,000 & 22 & 25.6 \\
\hline \multirow{4}{*}{$\begin{array}{l}\text { Local committee } \\
\text { establishment }\end{array}$} & Before 1900 & 2 & 2.3 \\
\hline & $1900 s-1950 s$ & 1 & 1.2 \\
\hline & $1950 s-2000 s$ & 27 & 31.4 \\
\hline & After 2000 & 56 & 65.1 \\
\hline
\end{tabular}




\section{Factor Analysis for Community Participation Strategies in Pre-Disaster Phase}

In order to use EFA, several tests should be used such as: justification for the sample size, Keiser-Meyer-Olkin (KMO) measure, Bartlett's test of sphericity and checking the anti-image correlation (Field, 2009), factors will be rotated in order to see if any variables should not be included in the intended constructs, communalities values, and the reliability of the chosen constructs will be tested through the Cronbach's alpha test (Cronbach, 1951).

The reliability of factor analysis is dependent on sample size. To obtain reliable results, the sample size in this research is 86 participants, which is more than 50 and considered adequate as proposed by Winter et al. (2009) and Zeller (2002). According to Pallant (2005), the correlations coefficient values should be above 0.9 and the correlations should be at least above 0.3. As it can be observed in the correlation matrix (as shown in Table 5), this requirement is satisfied. Other important initial tests are the Keiser-Meyer-Olkin (KMO) measure, Bartlett's test of sphericity and checking the anti-image correlation (Field, 2009). A measure KMO over 0.5 is barely acceptable, values between 0.5 and 0.7 are mediocre, values between 0.7 and 0.8 are good, values between 0.8 and 0.9 are great and values above 0.9 are superb (Kaiser, 1974). In this case, the KMO for all 24 variables was $0.41<0.5$, which is considered not enough for further analysis, while the value of Bartlett's test of sphericity is significant $(p=0.000)$. This meets the factor analysis requirement (Table 6).

Several trials (i.e., eleven runs) were conducted to remove the variables with measure of sampling adequacy (MSA) less than the threshold of 0.5 to increase KMO above 0.50 (Field, 2009). Consequently, 11 variables were removed (which have MSA value less than 0.5) resulted in increasing the KMO to 0.69, which satisfies factor analysis criteria. The removed 11 variables were (Community Participation - Pre-Disaster Strategies [CP-PDS] 1, CP-PDS2, CP-PDS4, CP-PDS6, CP-PDS7, CPPDS8, CP-PDS 10, CP-PDS11, CP-PDS15, CP-PDS 16 and CP-PDS21), which also lack sufficient correlation with other variables (Field, 2009). Table 7 shows the excluded statements (variables).

The principal component analysis was employed for extraction and rotation process for the remaining 10 variables. Factor loading (threshold equal to or more than 0.5) cross-loading (do not produce different mixes of variable within each component), eigenvalues (greater than 1.0) and scree plot were checked following Field (2009). As shown in Table 8, there were no factor loadings less than 0.50.

Table 9 and Figure 1 show that there were three eigenvalues greater than 1.0. The eigenvalue criterion stated that each component explained at least one variable's worth of the variability and therefore only components with eigenvalues greater than one should be retained (Larose, 2006; Field, 2009). The first component accounted for $37.69 \%$ of the total variance and named: preparing effective coordination and management plans, the second component explains $20.43 \%$ of the total variance, which named preparing information and knowledge systems and the third component accounted $11.13 \%$ and named providing early warning and communication plans. The three components accounted for $69.26 \%$ of the total variance. According to Pallant (2005), a value with a Cronbach's alpha higher than 0.7 is required in order to create a reliable construct of multiple variables. The Cronbach's alpha for all components are higher than 0.70, which is acceptable according to Pallant (2005). 


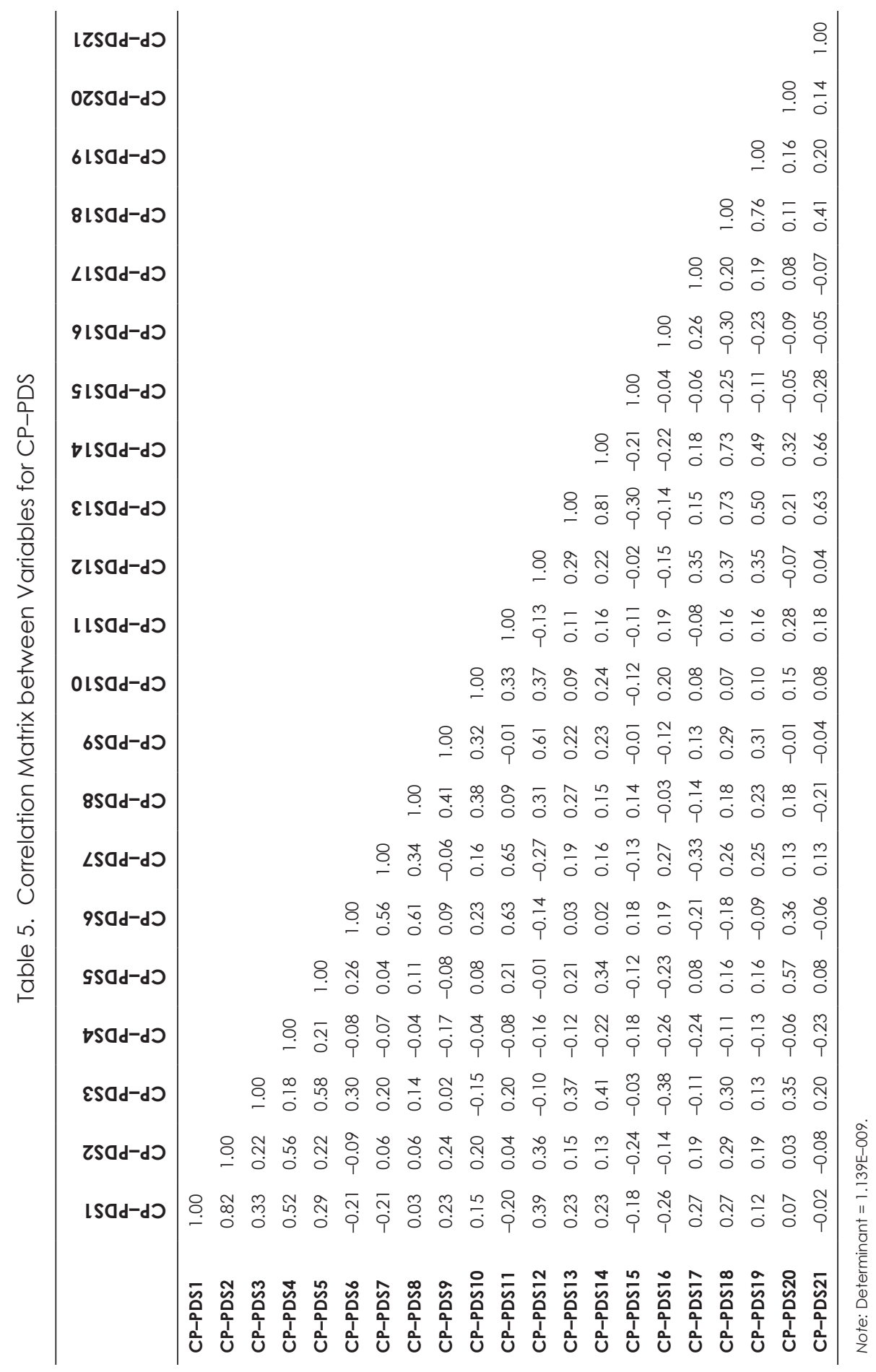


Table 6. Preliminary KMO and Bartlett's Test for 1st Run (PC-PDS)

\begin{tabular}{lcc}
\hline Kaiser-Meyer-Olkin Measure of Sampling Adequacy & $\mathbf{0 . 4 1}$ \\
\hline Bartlett's Test of Sphericity & Approx. chi-square & 1572.47 \\
& df & 210 \\
Cronbach's Alpha & & 0.000 \\
\hline
\end{tabular}

Table 7. Excluded Variables for CP-PDS

\begin{tabular}{|c|c|c|c|}
\hline CP-PDS & & Run & $\begin{array}{l}\text { Removal } \\
\text { Causes }\end{array}$ \\
\hline CP-PDS10 & $\begin{array}{l}\text { Disseminate information of disaster topics } \\
\text { and encourage public participation }\end{array}$ & First run & $(\mathrm{MSA}<0.5)$ \\
\hline CP-PDS8 & $\begin{array}{l}\text { Create a continuous dialogue between the } \\
\text { institutions and stakeholders }\end{array}$ & Second run & $(\mathrm{MSA}<0.5)$ \\
\hline CP-PDS6 & $\begin{array}{l}\text { Meet the various sectors which are related } \\
\text { to disaster management }\end{array}$ & Third run & $(\mathrm{MSA}<0.5)$ \\
\hline CP-PDS 11 & $\begin{array}{l}\text { Establish capability-building activities } \\
\text { between the community disaster } \\
\text { committees and the volunteers }\end{array}$ & Fourth run & $(\mathrm{MSA}<0.5)$ \\
\hline CP-PDS21 & $\begin{array}{l}\text { Draft capacity building programmes in a } \\
\text { bottom-up and demand-driven fashion }\end{array}$ & Fifth run & $(M S A<0.5)$ \\
\hline CP-PDS 1 & $\begin{array}{l}\text { Provide various educational backgrounds } \\
\text { regarding disaster management }\end{array}$ & Sixth run & $(M S A<0.5)$ \\
\hline CP-PDS 15 & $\begin{array}{l}\text { Providing psychological support for } \\
\text { communities }\end{array}$ & Seventh run & $(M S A<0.5)$ \\
\hline CP-PDS2 & $\begin{array}{l}\text { Provide appropriate community based } \\
\text { disaster preparedness plan }\end{array}$ & Eighth run & $(M S A<0.5)$ \\
\hline CP-PDS7 & $\begin{array}{l}\text { Strengthen the role of non-governmental } \\
\text { institutions to participate in disaster } \\
\text { management activities }\end{array}$ & Ninth run & $(M S A<0.5)$ \\
\hline CP-PDS4 & $\begin{array}{l}\text { Strengthen relationships between NGOs } \\
\text { and community-based organisations } \\
\text { related to disaster management }\end{array}$ & 10th run & $(\mathrm{MSA}<0.5)$ \\
\hline CP-PDS16 & Assess the impact of previous disasters & 11 th run & $(M S A<0.5)$ \\
\hline
\end{tabular}


Table 8. Communalities Values

\begin{tabular}{|c|c|c|c|}
\hline & CP-PDS & Initial & $\begin{array}{c}\text { Extraction } \\
\text { (Communalities) }\end{array}$ \\
\hline CPS-Pre3 & $\begin{array}{l}\text { Prepare information technology system } \\
\text { regarding disaster management }\end{array}$ & 1.00 & 0.62 \\
\hline CPS-Pre5 & $\begin{array}{l}\text { Propose public awareness programs and } \\
\text { preparedness knowledge }\end{array}$ & 1.00 & 0.79 \\
\hline CPS-Pre9 & Provide mitigation programs for risk disaster & 1.00 & 0.53 \\
\hline CPS-Pre 12 & $\begin{array}{l}\text { Provide early warning protocols and } \\
\text { evacuation plans }\end{array}$ & 1.00 & 0.75 \\
\hline CPS-Pre13 & $\begin{array}{l}\text { Coordinate between disaster management } \\
\text { and development (on the economic and } \\
\text { environmental levels) activities }\end{array}$ & 1.00 & 0.78 \\
\hline CPS-Pre14 & $\begin{array}{l}\text { Strengthen the capacities of related non- } \\
\text { governmental organisations }\end{array}$ & 1.00 & 0.79 \\
\hline CPS-Pre17 & $\begin{array}{l}\text { Utilise communication for disseminating } \\
\text { warning signals }\end{array}$ & 1.00 & 0.52 \\
\hline CPS-Pre18 & Preparing resources and coordination plans & 1.00 & 0.87 \\
\hline CPS-Pre19 & $\begin{array}{l}\text { Coordinate effective management with } \\
\text { operational planning }\end{array}$ & 1.00 & 0.61 \\
\hline CPS-Pre20 & Participate in risk assessment & 1.00 & 0.67 \\
\hline
\end{tabular}

Note: Extraction method: Principal Component Analysis

Table 9. Total Variance Explained of CP-PDS

\begin{tabular}{|c|c|c|c|c|c|c|c|c|c|}
\hline \multirow[b]{2}{*}{ 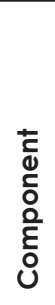 } & \multicolumn{3}{|c|}{ Initial Eigenvalues } & \multicolumn{3}{|c|}{$\begin{array}{l}\text { Extraction Sums of Squared } \\
\text { Loadings }\end{array}$} & \multicolumn{3}{|c|}{$\begin{array}{c}\text { Rotation Sums of Squared } \\
\text { Loadings }\end{array}$} \\
\hline & 훙 & 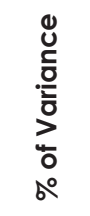 & 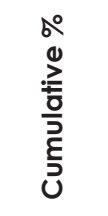 & 흠 & 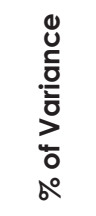 & 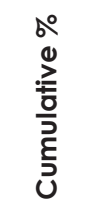 & 흥 & 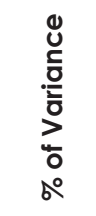 & 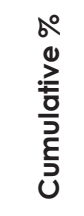 \\
\hline 1 & 3.77 & 37.69 & 37.69 & 3.77 & 37.69 & 37.69 & 3.07 & 30.71 & 30.71 \\
\hline 2 & 2.04 & 20.43 & 58.12 & 2.04 & 20.43 & 58.12 & 2.06 & 20.56 & 51.27 \\
\hline 3 & 1.11 & 11.13 & 69.26 & 1.11 & 11.13 & 69.26 & 1.80 & 17.99 & 69.26 \\
\hline 4 & 0.91 & 9.14 & 78.40 & & & & & & \\
\hline 5 & 0.65 & 6.46 & 84.86 & & & & & & \\
\hline 6 & 0.55 & 5.55 & 90.40 & & & & & & \\
\hline 7 & 0.39 & 3.86 & 94.26 & & & & & & \\
\hline 8 & 0.27 & 2.69 & 96.95 & & & & & & \\
\hline 9 & 0.18 & 1.76 & 98.71 & & & & & & \\
\hline 10 & 0.13 & 1.29 & 100.00 & & & & & & \\
\hline
\end{tabular}




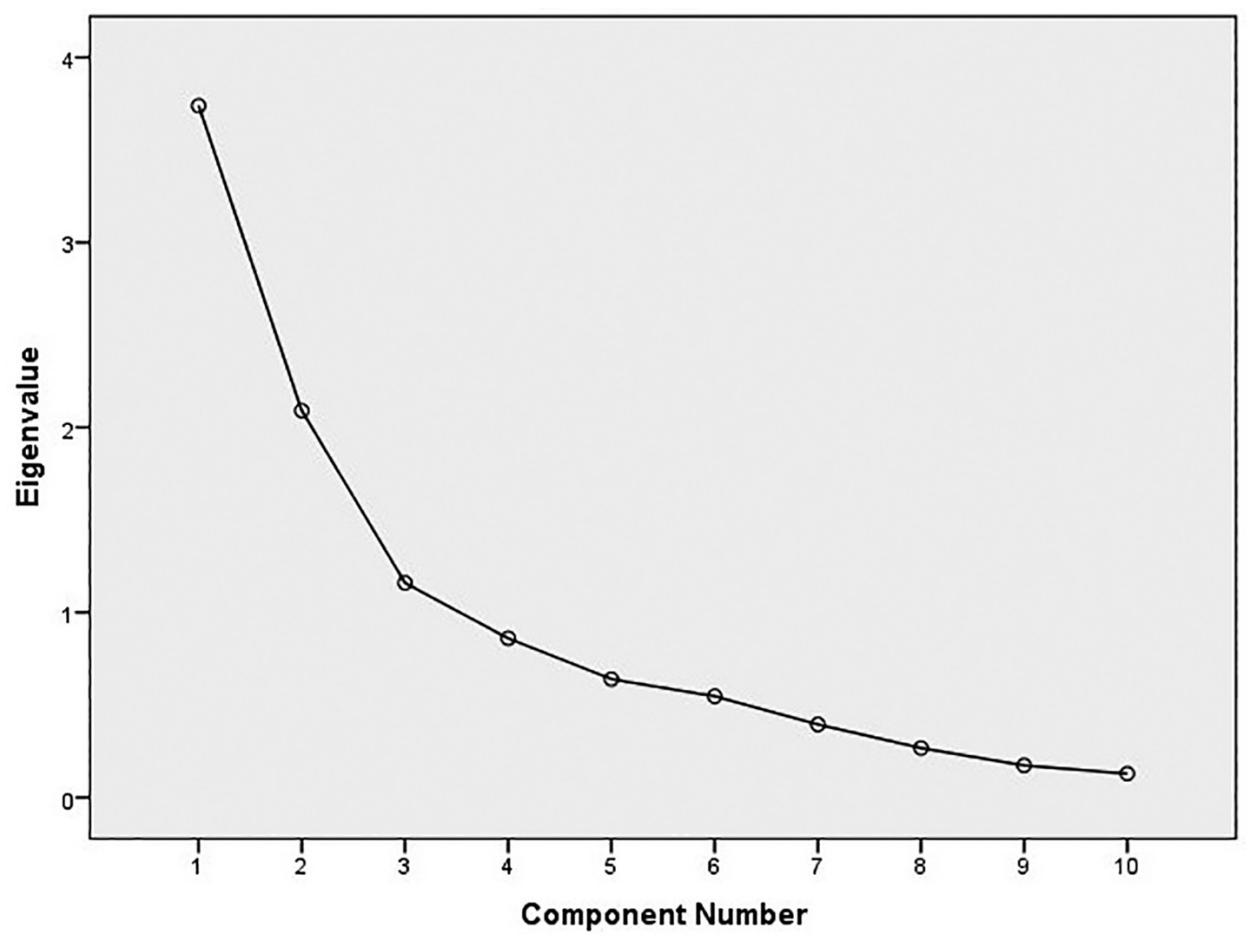

Figure 1. Scree plot for CP-PDS

\section{Discussion of the Components Resulted from EFA}

Each of the extracted components will be interpreted and discussed further as follows.

\section{Component 1: Preparing effective coordination and management plans}

According to results showed in Table 10, the first component which is "Preparing effective coordination and management plans" comprises four strategies related to community participation strategies in pre-disaster phase. This component includes the strategies related to effective coordination of the preparedness plans and capacity building of NGOs. The strategies factor loadings ranging from 0.72 to 091. Disaster preparedness planning leads organisational readiness in anticipation of an emergency in Gaza Strip; this includes emergency supplies and coordination procedures. Well-coordinated plan is essential for efficient and successful disaster response. This result is in line with Mathbor (2007) who stated that active involvement in disaster management, creating plans to link preparedness and coordination between parties makes bridge for vulnerable populations for required resources when disaster strikes. Furthermore, this result is consistent with Metri (2006) who claimed that NGOs can play important role by providing assistance in coordinating disaster management and development activities. 


\section{Component 2: Preparing information and knowledge systems}

The second component "Preparing information and knowledge systems" contains three strategies related to community participation strategies pre-disaster. The strategies have factor loadings ranging from 0.64 to 0.88 . Information is essential for assessing risk and potential vulnerability in the earliest stages of community planning or for individuals planning in Gaza Strip. Such information is also crucial when disaster threaten and when communities prepare to withstand the potential onset of disaster. Disaster data contains information largely driven by NGOs and local communities' considerations in pre-disaster activities. This result corroborates with Kangabam, C. and Kangabam (2012), Metri (2006) and Newport and Jawahar (2003) findings. They stated that disaster information among the community varies with the educational background and can be strengthened through a combination of appropriate community based disaster preparedness and information technology system.

Table 10. Results of Factor Analysis for CP-PDS

No.

Components of Community Participation Strategies in Pre-Disaster Phase

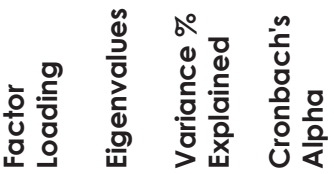

Component 1: Prepare effective coordination and management plans

$\begin{array}{lll}\text { CP-PDS18 } & \text { Preparing resources and coordination plans } & 0.91 \\ \text { CP-PDS13 } & \text { Coordinate between disaster management } & 0.86\end{array}$
and development (on the economic and environmental levels) activities

CP-PDS14 Strengthen the capacities of related NGOS

$\begin{array}{lll}\hat{N} & \stackrel{a}{0} & \infty \\ \dot{m} & \hat{m} & 0 \\ & 0\end{array}$

CP-PDS19

Coordinate effective management with

0.72

operational planning

Component 2: Prepare information and knowledge systems

CP-PDS3

CP-PDS20

CP-PDS5
Prepare information technology system regarding disaster management

$$
\text { Participate in risk assessment }
$$

Propose public awareness programs and preparedness knowledge
0.64

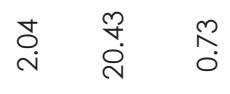

Component 3: Provide early warning and communication plans

$$
\text { CP-PDS } 12
$$

Provide early warning protocols and evacuation plans

CP-PDS 17

$$
\text { Utilise communication for disseminating }
$$
warning signals

CP-PDS9

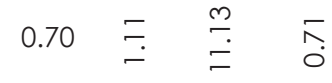

0.66

Notes: $\mathrm{KMO}$ measure of sampling adequacy $=0.69$; Bartlett's test of sphericity: $\times 2=407.49, \mathrm{df}=$ $45, p$-value $=0.00$; Total variance explained $(\%)=69.26 \%$; Total reliability Cronbach's alpha $=0.81$; Insignificant factor loadings (<0.5) are blanked. 


\section{Component 3: Providing early warning and communication plans}

The third component which is "Providing early warning and communication plans" comprises three strategies, which have factor loading ranging from 0.66 to 0.81. Aldabeek (2010) revealed that the risks threatening Gaza Strip cannot be prevented, but their human, socio-economic and environmental impacts can and should be minimised through appropriate measures, including early warning. It requires long-term plans; early warning should be seen as a strategy to effectively reduce the growing vulnerability of communities and assets. There is a need to disseminate early warning protocols of every type of risks in Gaza Strip for local communities. It can strengthen coordination and communication links by defining responsibility mechanisms and appropriate evacuation plans before disasters. This result is in agreement with Said et al. (2011), Mathbor (2007), Metri (2006), Newport and Jawahar (2003). They pointed out that the agencies indicated that the best method to warn the public of impending disasters through early warning protocols using media. In addition, many communication tools are currently available for warning dissemination such as, short cellular phone text messaging, e-mail, radio, television and web service. Information and communication technology is a key element in early warning. It plays an important role in disaster communication and dissemination of information to organisations in order to response to disasters.

\section{CONCLUSION AND RECOMMENDATIONS}

The objective of this paper was to identify and explore the strategies that are utilised by local communities in the Gaza Strip, Palestine in pre-disaster stage. The factor analysis resulted in three components: preparing effective coordination and management plans, preparing information and knowledge systems and providing early warning and communication plans. Disaster preparedness planning leads organisational readiness in anticipation of an emergency in Gaza Strip; this includes emergency supplies and coordination procedures. Information is essential for assessing risk and potential vulnerability in the earliest stages of community planning or for individuals planning in Gaza strip. Disaster data contains information largely driven by NGOs and local communities' considerations in pre-disaster activities.

Risks threatening Gaza Strip cannot be prevented, but their human, socioeconomic and environmental impacts can and should be minimised through appropriate measures, including early warning. There is a need to disseminate early warning protocols of every type of risks in Gaza Strip for local communities. NGOs in Gaza governorates require a common understanding of what creates effective disaster preparedness system including and understanding of disaster risk factors pre-disaster. The early warning system in Gaza governorates is considered weak and need to be developed. The findings of this research will be significant concerning the present and future of organisational planning and management by both governmental and NGOs regarding disaster management practice. 


\section{REFERENCES}

Abramovitz, J., Banuri, T., Girot, P., Orlando, B., Schneider, N., Siegfried, E., Switzer, J. and Hammill, A. (2001). Adapting to Climate Change: Natural Resource Management and Vulnerability Reduction. Gland, Switzerland: International Union for Conservation of Nature and Natural Resources. Available at: https://www.iisd.org/pdf/2002/envsec_cc_bkgd_paper.pdf [Accessed on 2 November 2014].

Aldbeek, J. (2010). An assessment on disaster risk reduction in the occupied Palestinian territory. Al-Najah University Journal for Research: A (Natural Sciences), 24(1): 1-46.

Anderson, R. (2004). Intuitive inquiry: An epistemology of the heart for scientific inquiry. The Humanistic Psychologist, 32(4): 307-341. https://doi.org/10.1080/ 08873267.2004 .9961758$.

Asian Disaster Preparedness Centre (ADPC) (2004). Program Completion Report: Asian Urban Disaster Mitigation Program. Bangkok: ADPC.

Baas, S., Ramasamy, S., De Pryck, J. and Battista, F. (2008). Disaster Risk Management System Analysis: A Guide Book. Rome: Institution for Disaster Risk Management. Available at www.fao.org [Accessed on 25 April 2017].

Barakat, S. (2003). Housing reconstruction after conflict and disaster. Network Paper, No. 43. London: Overseas Development Institute.

Bartholomew, D., Knotts, M. and Moustaki, I. (2011). Latent Variable Models and Factor Analysis: A Unified Approach. 3rd Ed. West Sussex, UK: John Wiley and Sons. https://doi.org/10.1002/9781119970583.

Coppola, D.P. (2015). Chapter 1: The management of disasters. In Introduction to International Disaster Management. 3rd Ed. Boston: Butterworth-Heinemann, 1-35. https://doi.org/10.1016/B978-0-12-801477-6.00001-0.

Cronbach, L.J. (1951). Coefficient alpha and the internal structure of tests. Psychometrika, 16: 297-334. https://doi.org/10.1007/BF02310555.

Cyganik, K.A. (2003). Disaster preparedness in Virginia Hospital Center-Arlington after Sept. 11, 2001. Disaster Management and Response, 1(3): 80-86. https://doi.org/10.1016/S1540-2487(03)00048-8.

Enshassi, A. and Abu Zaiter, M. (2013). Self-help approach in housing reconstruction and beneficiaries' satisfaction in Palestine. Proceedings of the USMCA 2013: 12th International Symposium on New Technologies for Urban Safety of Mega Cities in Asia (Seiken Sympsium 75). Tokyo: International Center for Urban Safety Engineering (ICUS).

Enshassi, A. and Shakalaih, S. (2016). Community based disaster risk reduction: a case study from the Gaza Strip. Proceedings of 2016 International Conference on Disaster Management and Coastal Engineering (ICDMCE 2016). Kyoto: ICDMCE.

Enshassi, A. and Shatat, T. (2012). Post disaster housing damage assessment in the Gaza Strip-Palestine. Proceedings of the 37th IAHS World Congress: Vision for the Future Housing; Mega Cities. Istanbul: Istanbul Technical University.

Federal Emergency Management Agency (FEMA) (2017). Report on Pre-Disaster Recovery Planning Guide for Local Governments. Washington DC: FEMA. Available at: https://www.fema.gov/media-library-data [Accessed on 1 May 2017] 
(2000). Report on Costs and Benefits of Natural Disaster Mitigation. Washington DC: FEMA. Available at: www.fema.gov/pdf/library [Accessed on 2 November 2014].

Field, A. (2009). Discovering Statistics Using SPSS. 3rd Ed. London: SAGE Publications Ltd.

Haddow, D. and Bullock, J. (2006). Introduction to Emergency Management. 2nd Ed. Oxford: Butterworth-Heinemann.

Holloway, A. (2003). Disaster risk reduction in Southern Africa: Hot rhetoric, cold reality. African Security Review, 12(1): 1-12. https://doi.org/10.1080/1024602 9.2003.9627568.

Hossain, M.A. (2012). Community participation in disaster management: Role of social work to enhance participation. Antrocom Online Journal of Anthropology, 9(1): 159-171.

Hosseini, K., Hosseini, M., Izadkhah, Y., Mansouri, B. and Shaw, T. (2014). Main challenges on community-based approaches in earthquake risk reduction: case study of Tehran, Iran. International Journal of Disaster Risk Reduction, 8: 114-124. https://doi.org/10.1016/j.ijdrr.2014.03.001.

Huq, S.M.S. (2016). Community based disaster management strategy in Bangladesh: Present status, future prospects and challenges. European Journal of Research in Social Sciences, 4(2): 22-35.

International Federation of Red Cross and Red Crescent Societies (IFRC) (2000). Introduction to Disaster Preparedness: Disaster Preparedness Training Programme. Geneva: IFRC. Available at: http://www.ifrc.org/Global/ Publications/disasters/all.pdf [Accessed on 2-11-2014].

Kangabam, R.D., C, P.P. and Kangabam, M. (2012). Disaster preparedness among the resident community: A case study of Rajiv Gandhi University, Itanagar, India. International Journal of Environmental Sciences, 2(3): 1632-1642.

Kapucu, N. (2008). Collaborative emergency management: Better community organizing, better public preparedness and response. Disasters, 32: 239-262. https://doi.org/10.1111/j.1467-7717.2008.01037.x.

Kapucu, N. and Garayev, V. (2011). Collaborative decision: Making in emergency and disaster management. International Journal of Public Administration, 34(6) 366-375. https://doi.org/10.1080/01900692.2011.561477.

Kent, R. (1994). Disaster Preparedness. 2nd Ed. Madison, WI: United Nations Disaster Management Training Programme (UNDMTP), Disaster Management Training Programme (DMTP) in association with the University of Wisconsin DisasterManagement Center.

Khan, H. and Khan, A. (2008). Natural hazards and disaster management in Pakistan. Munich Personal RePEc Archive (MPRA) Paper No. 11052: 16.

Larose, D. (2006). Discovering Statistics. 3rd Ed. New York: W.H. Freeman and Company.

Mathbor, G. (2007). Enhancement of community preparedness for natural disasters: The role of social work in building social capital for sustainable disaster relief and management. International Social Work, 50(3): 357-369. https://doi. org/10.1177/0020872807076049.

McEntire, A. (2005). Why vulnerability matters, exploring the merit of an inclusive disaster reduction concept. Disaster Prevention and Management, 14(2): 206-222. https://doi.org/10.1 108/09653560510595209. 
Mengers, H. (2000). Making urban sector lending work: Lessons from a capacity building programme in Karnataka, India. Habitat International, 24(4): 375390. https://doi.org/10.1016/S0197-3975(00)00004-7.

Metri, B. (2006). Disaster mitigation framework for India using quality circle approach. Disaster Prevention and Management, 15(4): 621-635. https://doi. org/10.1108/09653560610686577.

Murshed, Z. (2003). Community capacity building for risk reduction in South Asia. In P. Sahni and M.M. Ariyabandu (eds.), Disaster Risk Reduction in South Asia. New Delhi: Prentice-Hall of India.

Newport, J. and Jawahar, G. (2003). Community participating and public awareness in disaster mitigation. Disaster Prevention and Management, 12(1): 33-36. https://doi.org/10.1108/09653560310463838.

Nirupama, N. and Etkin, D. (2012). Institutional perception and support in emergency management in Ontario, Canada. Disaster Prevention and Management, 21 (5): 599-607. https://doi.org/10.1108/09653561211278725.

Palakudiyil, T. and Todd, M. (2003). Facing up to the storm: How local communities can cope with disaster. Humanitarian Practice Network, 1 (25): 37-39.

Pallant, J. (2005). SPSS Survival Manual: A Step by Step Guide to Data Analysis Using SPSS for Windows (Version 12). Berkshire, England: Open University Press.

Parahoo, K. (1997). Nursing Research: Principles, Process and Issues. Basingstoke: Macmillan Press Ltd. https://doi.org/10.1007/978-1-349-14559-1.

Polit, D. and Hungler, B. (1999). Nursing Research: Principles and Methods. 6th Ed. Philadelphia: JB Lippincott.

Practical Action (2011). Strengthen Livelihood Capacities to Disaster Risk ReductionCompilation of Change Studies. Kathmandu: Practical Action.

Rajeev, M.M. (2014). Sustainability and community empowerment in disaster management. International Journal of Social Work and Human Services Practice, 2(6): 207-212.

Ritchie, G.N. (2003). Disaster risk reduction by education, information and public awareness. In P. Sahni and M.M. Ariyabandu (eds.), Disaster Risk Reduction in South Asia. New Delhi: Prentice-Hall of India.

Sadiqi, Z., Trigunarsyah, B. and Coffey, V. (2015). Community participation in post disaster reconstruction. Municipal Engineer, 169(ME3): 173-186. https://doi. org/10.1680/muen.15.00016.

Said, A., Ahmadun, F., Mahmud, A. and Abas, F. (2011). Community preparedness for tsunami disaster: A case study. Disaster Prevention and Management, 20(3): 266-280. https://doi.org/10.1108/09653561111141718.

Stephenson, R. (1994). Disaster Assessment. 2nd Ed. Madison, WI: United Nations Disaster Management Training Programme (UNDMTP), Disaster Management Training Programme (DMTP) in association with the University of Wisconsin Disaster-Management Center.

Twigg, J. (2004). Natural Disaster Mitigation and Preparedness Activities. London: Humanitarian Practice Network (HPN).

United Nations Development Programme (UNDP) (2009). Human Development Report 2009/10 Occupied Palestinian Territory: Investing in Human Security for a Future State. Jerusalem: UNDP. Available at: http://hdr.undp.org/sites/ default/files/nhdr_palestine_en_2009-10.pdf [Accessed on 25 April 2015]. 
United Nations International Strategy for Disaster Reduction (UNISDR) (2010). Making Cities Resilient: My City is Getting Ready (2010-2011 World Disaster Reduction Campaign). Geneva: UNISDR. Available at: http://www.unisdr. org/campaign/resilientcities.

. (2009). Terminology on Disaster Risk Reduction. Geneva: UNISDR. Available at: https://www.unisdr.org/we/inform/terminology [Accessed on 2 November 2014].

. (2004). Living with Risk: A Global Review of Disaster Reduction Initiatives. Vol. 2. New York and Geneva: UNISDR. Available at: http://www.unisdr.org/ files/657_Iwr21.pdf [Accessed on 2 November 2014].

Vasilescu, L., Khan, A. and Khan, H. (2008). Disaster management cycle: A theoretical approach. Journal of Management and Marketing, 6(1): 43-50.

Venton, P. and Hansford, B. (2006). ROOTS 9: Reducing Risk of Disaster in Our Communities. Teddington, UK: Tearfund. Available at: http://tilz.tearfund.org/ [Available on 25 April 2015].

Warfield, C. (2008). The disaster management cycle. Available at: http://www.gdrc. org/vem/disasters/1-dm_cycle.html [Accessed on 2 November 2014].

Wiek, A., Ries, R., Thabrew, L., Brundiers, K. and Wickramasinghe, A. (2010). Challenges of sustainable recovery processes in tsunami affected communities. Disaster Prevention and Management, 19(4): 423-437. https://doi.org/10.1108/09653561011070358.

Wisner, B., Blaikie, P., Cannon, T. and Davis, I. (2003). At Risk: Natural Hazards, People's Vulnerability and Disasters. 2nd Ed. London: Routledge.

Yong, A. and Pearce, S. (2013). A beginner's guide to factor analysis: Focusing on exploratory factor analysis. Tutorials in Quantitative Methods for Psychology, 9(2): 79-94. https://doi.org/10.20982/tqmp.09.2.p079. 